Cumhuriyet International Journal of Education-CIJE

e-ISSN: 2147-1606

Vol 4 (1), 2015, $21-34$

\title{
The Relationship Between The Attitudes Towards Teaching Profession and The Anxiety Level of Prospective Primary School Teachers
}

\author{
Mehmet Koray SERİN1, Ahmet Melih GÜNEŞ², Hatice DEĞİRMENCİ3
}

\section{Summary}

\section{INTRODUCTION}

General knowledge, field information and teaching competency are the qualities a teacher should have. However, a teacher 's emotional reactions are seen to be critical as well. The emotional reactions include teachers' and prospective teachers' interests, attitudes, concerns, values and tendencies. Accordingly, a teacher who has a positive attitude towards her/his job can be said to be a good teacher. Besides, it is possible to say that various levels of anxiety can affect a prospective teacher's attitudes towards teaching; therefore, it can impact her/his behaviours in the basic education, which is quite important. The current study aims to determine the relationship between prospective class teachers' attitudes towards teaching and their anxiety level by answering the following questions:

1. What are the perceived professional anxiety levels of prospective teachers?

2. What are the attitudes of prospective class teachers towards teaching profession?

3. Is there any difference between the prospective class teachers' anxiety levels in terms of the year that are studying at university?

4. Is there any difference between the prospective class teachers' attitudes towards teaching profession in terms of the year that are studying at university?

5. What is the relationship between the prospective teachers' professional anxiety levels and attitudes towards teaching profession?

\section{METHOD}

In this study relational screening model was used to determine the relationship between the anxiety levels and attitudes towards teaching profession of prospective class teachers. The sample of the study comprised the prospective teachers studying at Kastamonu University Education Faculty and Gazi Universirty Education Faculty. The related scales were applied to all the students in the primary school class teaching department. When the incomplete or wrongly filled questionnaires were eliminated, 763 questionnaires were taken into assessment. In the study, "Prospective Teachers' Anxiety Scale" developed by Borich and adapted by Saban, Korkmaz and Akbaşlı and "Attitudes towards Teaching Profession Scale" developed by Üstüner were used. Obtained data were analyzed using SPSS 20: Pearson product moment correlation coefficient and variance analysis techniques were used.

\section{FINDINGS}

When the data related to prospective teachers' anxiety levels were analyzed, the anxiety levels of them were found to be at a moderate level. The analysis of the data related to anxiety levels in terms of dimensions reveal that prospective teachers will experience selfcentered anxiety and student -centered anxiety. The analysis of the data related to attitudes

\footnotetext{
${ }^{1}$ Res. Assist. PhD., Kastamonu University, Faculty of Education, m.koray_serin@hotmail.com

2 Ministry of National Education, melihgunes@gmail.com

${ }^{3}$ Assist. Prof., Aksaray University, Faculty of Education, haticedegirmenci07@hotmail.com
} 
towards teaching profession reveal that prospective teachers' answers to the scale were "agree" and their attitudes towards teaching profession were positive above average. Prospective teachers' level of anxiety related to teaching profession and their attitudes towards teaching did not show any significant difference in terms of the year they are studying at the university. The relationship between their anxiety level and attitudes towards teaching profession was found to be at a moderate level. There is also a negative and relationship between the subdimensions of prospective teachers' anxiety level and their attitudes towards teaching profession at a moderate level. And there is a negative relationship between student-centered anxiety and attitudes towards teaching profession at a low level. These findings indicate that if primary school class teachers develop positive attitudes towards teaching profession, their level of anxiety drops off or if they experience high levels of anxiety towards teaching, they may develop negative attitudes towards their profession. 